\title{
Micropalaeontological dating of the basal Cretaceous section of DSDP Site 249, Leg 25, Mozambique Ridge: implications for the timing of the southern Atlantic-Indian Ocean connection
}

\author{
Robert E. Dunay ${ }^{1}$, William Braham ${ }^{2, \dagger}$, M. Kevin E. Cooper ${ }^{3}$, Martin Lester ${ }^{3}$, and Fabrizio Tremolada ${ }^{3}$ \\ ${ }^{1}$ ExxonMobil International Ltd, ExxonMobil House, Ermyn Way, Leatherhead KT22 8UX, UK \\ ${ }^{2}$ Consultant biostratigrapher \\ ${ }^{3}$ RPS Energy, Goldvale House 27-41 Church Street West, Woking, Surrey GU21 6DH, UK \\ $\dagger$ deceased \\ Correspondence: Robert E. Dunay (bob.e.dunay@exxonmobil.com) \\ Published: 9 February 2018
}

\begin{abstract}
Tectonic models suggest the absence of a deep water connection on the Mozambique Ridge during early Neocomian time. These models imply the initiation of a deep water connection between the southern Atlantic and Indian oceans formed during Barremian-earliest Aptian times. However, previous biostratigraphic studies of the earliest deep water sediments on the Mozambique Ridge suggest that the basal section is Neocomian in age. Here, we present a new biostratigraphic analysis undertaken to test this tectonic model and determine the earliest age of deep water sedimentation on the Mozambique Ridge. Core samples from the Cretaceous interval 222.05-406.32 m (Cores 19-32) of DSDP Site 249, Leg 25, were sampled for calcareous nannoplankton and palynological analysis. Most of the sampling was concentrated on the Lower Cretaceous interval below $294 \mathrm{~m}$. Our results indicate that the lower sedimentary section is no older than Barremian and therefore provides support for the age proposed by the tectonic models.
\end{abstract}

\section{Introduction}

Site 249 of the DSDP Leg 25 was drilled in 1972 at a water depth of $2088 \mathrm{~m}$ on the Mozambique Ridge (Fig. 1). The total penetration of the borehole was 412 , with $408 \mathrm{~m}$ of sedimentary section (Cores $1-32$ ) overlying $3.1 \mathrm{~m}$ of highly vesicular theolithic basement basalt (Core 33). The borehole penetrated Miocene sediments unconformably overlying Upper Cretaceous. Shipboard biostratigraphic data identified the top Cenomanian/Lower Cretaceous section at $294 \mathrm{~m}$ (Core 24) with top Neocomian hypothesized at $313 \mathrm{~m}$ (Core 26).

Previous biostratigraphic analyses concentrated on calcareous nannoplankton (Shipboard Scientific Party, 1974a; Bukry, 1974), foraminifera (Shipboard Scientific Party, 1974a; Riegraf, 1989), and radiolaria (Sanfilippo and Riedel, 1974). Bukry (1974) describes a diverse Campanian assemblage (E. augustus Zone) at $263 \mathrm{~m}$ (Core 21) and proba- ble early Aptian assemblages at 332-398 m (Cores 28-31), including Micrantholithus obtusus, Vagalopilla matalosa, and the ubiquitous Watznaueria barnesiae. An assemblage at $390 \mathrm{~m}$ (Core 31) contains abundant W. barnesiae, common M. obtusus and V. matalosa, as well as C. crenulatus, M. hoschulzii, P. asper, and P. embergeri, among others. Bukry (1974) suggests that his age determination is supported by the absence of Albian and younger taxa such as Cribosphaera and Eiffellithus. as well as the absence of $\mathrm{Cru}$ ciellipsis cuvillieri, which is indicative of Hauterivian. Lees (2002) re-analysed the Late Cretaceous section of Site 249. She assigned this section to the Campanian based on the presence of Eiffellithus eximius and Eiffellithus sissinghii. She considered that the Campanian sat unconformably on late Aptian and older based on an occurrence of Farhania varolii. A brief report indicates that radiolaria were recovered, but no firm stratigraphic conclusions were proposed although as- 


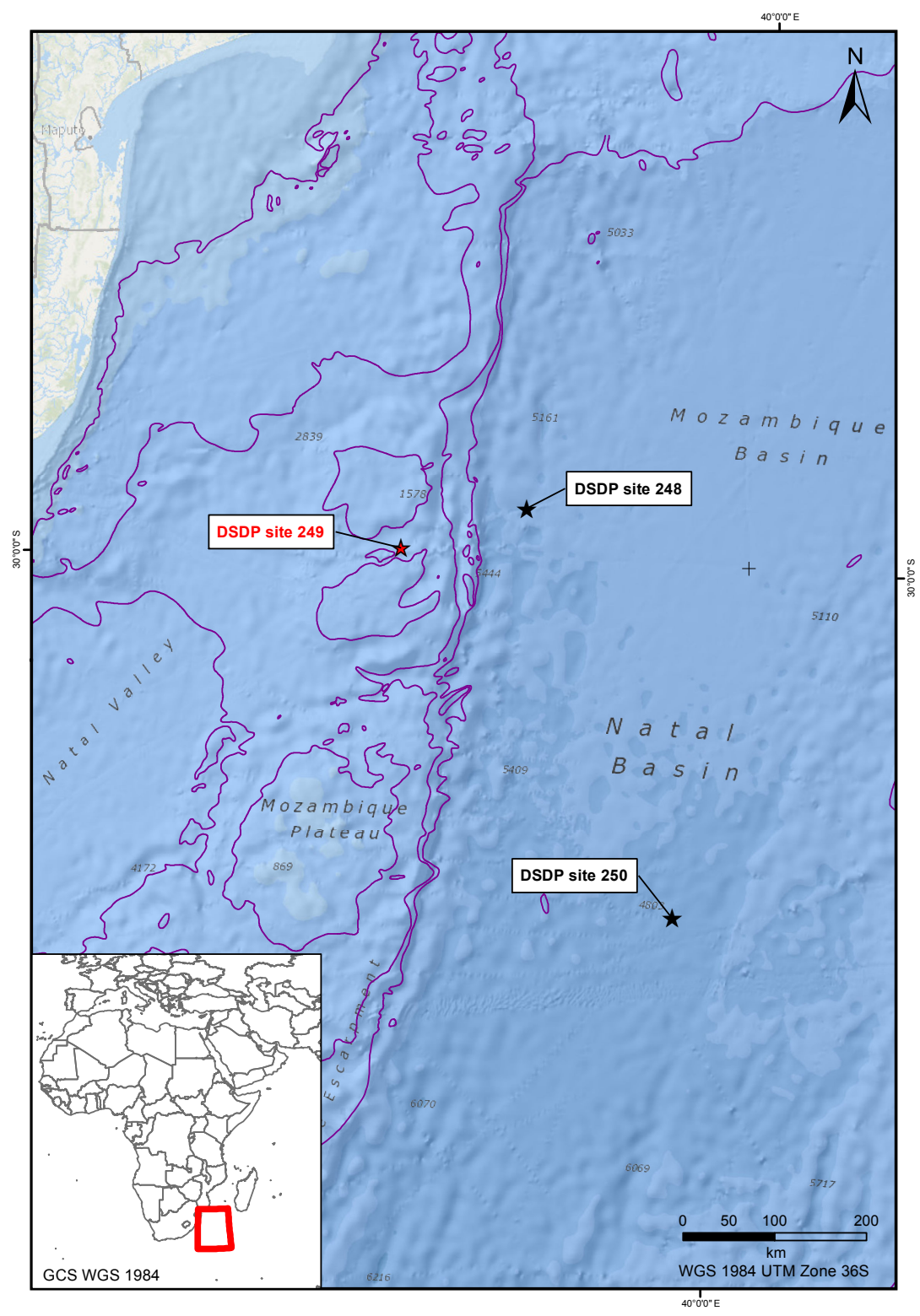

Figure 1. Location map of DSDP core holes on the Mozambique Ridge (DSDP 249) and Mozambique/Natal basins (DSDP 248, 250).

semblages from Cores 23-3 to 26-2 (287-315 m) appeared to be of "early Late Cretaceous" aspect (Sanfilippo and Riedel, 1974). Foraminiferal studies undertaken on board ship generally reported benthic forams (as well as some ostracods). Samples over the interval 294-313 m (Cores 24-26) contain small globigerinids of Aptian-Barremian aspect. Samples below $322 \mathrm{~m}$ contain ostracods and benthic forams. The authors suggest a Hauterivian-Valanginian age for the basal section. Riegraf (1989) in his study of 12 radiolarian-rich claystones from the interval 322-398 m (Cores 26-2 to 31-3) reaches a similar conclusion and assigns this interval to the Hauterivian-Valanginian. As abundant radiolaria are generally considered indicators of deep water, Riegraf considers the benthic foraminifera assemblages, which are indicative of shelf habitats, to be reworked into deeper water.

The current study was undertaken to determine the earliest age of marine sedimentation on the Mozambique Ridge. Previous investigations, based principally on benthic foraminifera, proposed a Neocomian age (taken here and in the previous biostratigraphic studies to encompass the Berriasian-Hauterivian). Recent models for the Mozambique Ridge favour a magmatic origin (Koenig and Jockat, 2010; Maria et al., 1990), although a continental origin has been previously proposed (Tucholke et al., 1981). The ridge represents over-thickened oceanic crust generated during anomalous spreading activity at the complex triple junction between 
Table 1. DSDP 249: list of samples with core numbers and depths (from sea floor) analysed for nannofossils and palynology.

\begin{tabular}{|c|c|c|c|c|c|c|}
\hline ODP Core Sample & $\begin{array}{r}\text { Top depth } \\
\text { (m CSF-A) }\end{array}$ & $\begin{array}{r}\text { Bottom depth } \\
(\mathrm{m} \text { CSF-A })\end{array}$ & $\begin{array}{r}\text { Top depth } \\
(\mathrm{m} \text { CSF-B) }\end{array}$ & $\begin{array}{r}\text { Bottom depth } \\
(\mathrm{m} \text { CSF-B) }\end{array}$ & Palynology & Nannofossils \\
\hline U0249Z-19R-3 W, 103.0-105.0 cm & 222.03 & 222.05 & 222.03 & 222.05 & $x$ & $x$ \\
\hline U0249Z-22R-1 W, 70.0-72.0 cm & 275.7 & 275.72 & 275.7 & 275.72 & & $x$ \\
\hline U0249Z-23R-4 W, 108.0-110.0 cm & 289.58 & 289.6 & 289.58 & 289.6 & & $x$ \\
\hline U0249Z-23R-5 W, $106.5-108.5 \mathrm{~cm}$ & 291.065 & 291.085 & 291.065 & 291.085 & $x$ & \\
\hline U0249Z-24R-1 W, 88.0-90.0 cm & 294.88 & 294.9 & 294.88 & 294.9 & $x$ & \\
\hline U0249Z-24R-1 W, $135.0-137.0 \mathrm{~cm}$ & 295.35 & 295.37 & 295.35 & 295.37 & & $x$ \\
\hline U0249Z-25R-1 W, $120.0-122.0 \mathrm{~cm}$ & 304.2 & 304.22 & 304.2 & 304.22 & & $x$ \\
\hline U0249Z-25R-3 W, 22.5-25.0 cm & 306.225 & 306.25 & 306.225 & 306.25 & $x$ & \\
\hline U0249Z-25R-3 W, 83.5-85.0 cm & 306.835 & 306.855 & 306.835 & 306.855 & & $x$ \\
\hline U0249Z-25R-3 W, $121.0-123.0 \mathrm{~cm}$ & 307.21 & 307.23 & 307.21 & 307.23 & $x$ & $x$ \\
\hline U0249Z-26R-1 W, 62.0-64.0 cm & 313.62 & 313.64 & 313.62 & 313.64 & $x$ & \\
\hline U0249Z-26R-2 W, $110.0-112.0 \mathrm{~cm}$ & 315.6 & 315.62 & 315.6 & 315.62 & & $x$ \\
\hline U0249Z-27R-1 W, $120.0-122.0 \mathrm{~cm}$ & 323.2 & 323.22 & 323.2 & 323.22 & & $\times$ \\
\hline U0249Z-27R-3 W, $121.0-123.0 \mathrm{~cm}$ & 326.21 & 326.23 & 326.21 & 326.23 & $x$ & \\
\hline U0249Z-28R-1 W, $21.0-23.0 \mathrm{~cm}$ & 332.21 & 332.23 & 332.21 & 332.23 & & $x$ \\
\hline U0249Z-28R-1 W, 68.0-70.0 cm & 332.68 & 332.7 & 332.68 & 332.7 & $x$ & $x$ \\
\hline U0249Z-29R-1 W, 53.0-55.0 cm & 351.53 & 351.55 & 351.53 & 351.55 & & $x$ \\
\hline U0249Z-29R-1 W, $146.0-148.0 \mathrm{~cm}$ & 352.46 & 352.48 & 352.46 & 352.48 & $x$ & \\
\hline U0249Z-30R-1 W, $120.0-122.0 \mathrm{~cm}$ & 371.2 & 371.22 & 371.2 & 371.22 & $x$ & $x$ \\
\hline U0249Z-30R-2 W, 24.0-26.0 cm & 371.74 & 371.76 & 371.74 & 371.76 & $x$ & \\
\hline U0249Z-31R-2 W, 30.0-31.0 cm & 390.8 & 390.81 & 390.8 & 390.81 & $x$ & \\
\hline U0249Z-31R-4 W, 34.0-35.0 cm & 393.84 & 393.85 & 393.84 & 393.85 & & $x$ \\
\hline U0249Z-32R-1 W, $130.0-132.0 \mathrm{~cm}$ & 406.3 & 406.32 & 406.3 & 406.32 & $x$ & $x$ \\
\hline
\end{tabular}

Africa, Antarctica, and South America. Magmatic models are supported by recent refraction seismic observations (Koenig and Jokat, 2010; Maria et al., 1990), DSDP penetrations of basement at Sites 249 and 248, and numerous plate tectonic models.

Tectonic models by Koenig and Jokat (2006) suggest that the Mozambique Ridge was an effective barrier to deep water connection between the southern Atlantic and Indian oceans until at least the basal Barremian. By late Barremian/early Aptian time the tectonic models indicate deep water connectivity had been established. The objective of this biostratigraphic study at DSDP Site 249 was to establish the earliest age of the deep marine sedimentary package present on the Mozambique Ridge and therefore the timing of the southern Atlantic-Indian Ocean connection.

A total of 23 core samples were obtained from the ODP curator for palaeontological analysis over the interval 222.5406.3 m (Cores 19-3 to 32-1). Calcareous nannofossils were re-examined in 15 samples in order to generate a quantitative dataset. Also, 13 samples were examined for palynology and a quantitative dataset was likewise generated. The sample and fossil group selection were made based on lithology. The three uppermost samples (222.05, 275.72, 289.6 m) were taken in overlying Upper Cretaceous Chalk. The remaining samples were taken from the generally Lower Cretaceous dark silty claystones and volcanic siltstones at and below $291.09 \mathrm{~m}$ (Core 23-5, 106.5-108.5 m). The sample and anal- ysis listings with core depths from sea-bed and DSDP core notation are provided on Table 1.

\section{Preparation techniques}

Both suspended/pipette strew and centrifuge slides were produced for nannofossil examination. The suspended/pipette strew technique takes generally a teaspoon (less if there is small amount of sample) of washed sample. These are wrapped in a paper towel and crushed by a hammer. The powdered sediment is placed into a plastic cup/glass beaker and distilled water is added. Generally a deflocculant (sodium hexametaphosphate) is added to the distilled water. The sample is stirred and subjected to ultrasonication for $10 \mathrm{~min}$ and then left to disintegrate for several hours (generally overnight). A small amount of the suspension is decanted into a vial and diluted with distilled water. This is pipetted on to a glass slide and dried on a hotplate.

For the centrifuge slide the suspension in the beaker is left for several hours and then decanted into a test tube and centrifuged for $30 \mathrm{~s}$ at $350 \mathrm{rpm}$. The suspended liquid is decanted into a test tube and the residue sediment at the base of test tube is discarded. Distilled water is added and the sample is spun at $850 \mathrm{rpm}$ for $30 \mathrm{~s}$. The liquid is discarded and the residue sediment is retained. More distilled water is added and the sample is spun again at $850 \mathrm{rpm}$ for $30 \mathrm{~s}$. The suspended liquid is discarded and a small amount of distilled 


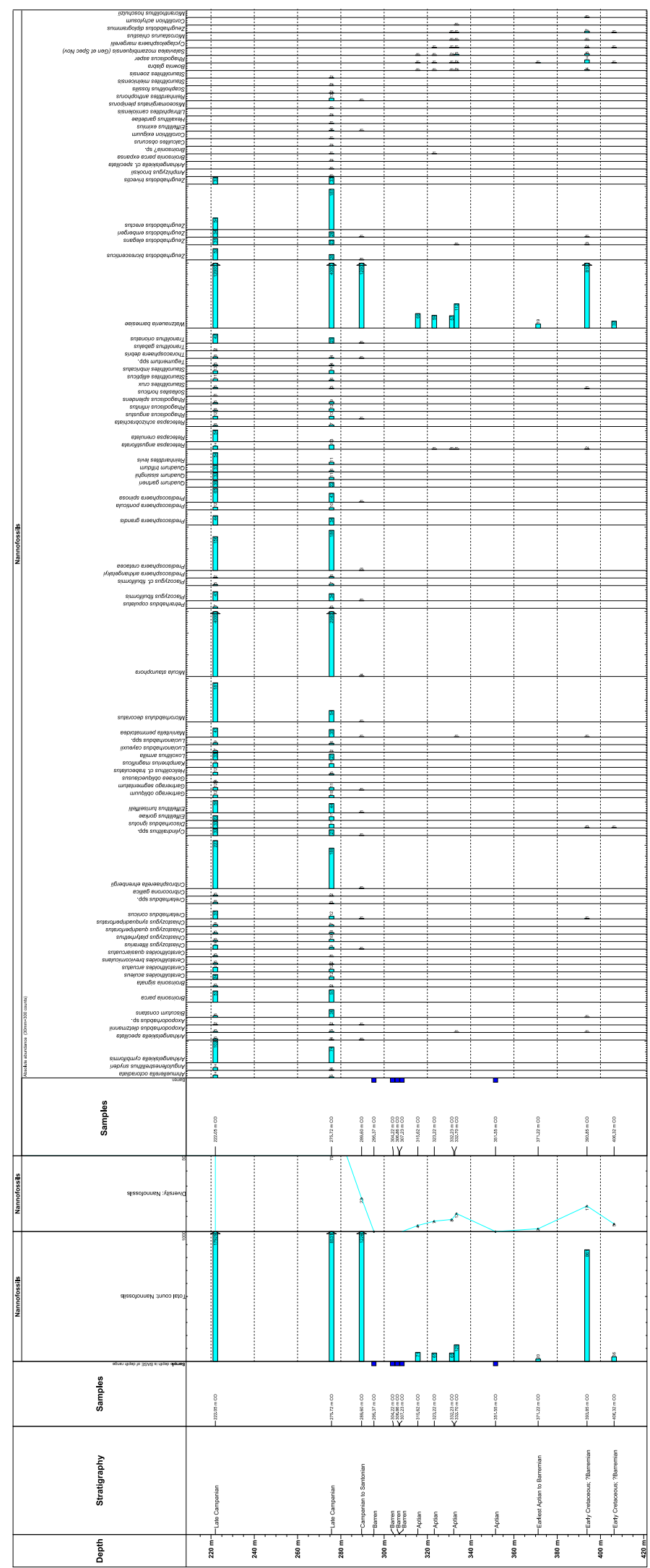

Figure 2. Calcareous nannoplankton fossil distribution chart. Total nannofossil count and species diversity per core (CO) sample. 


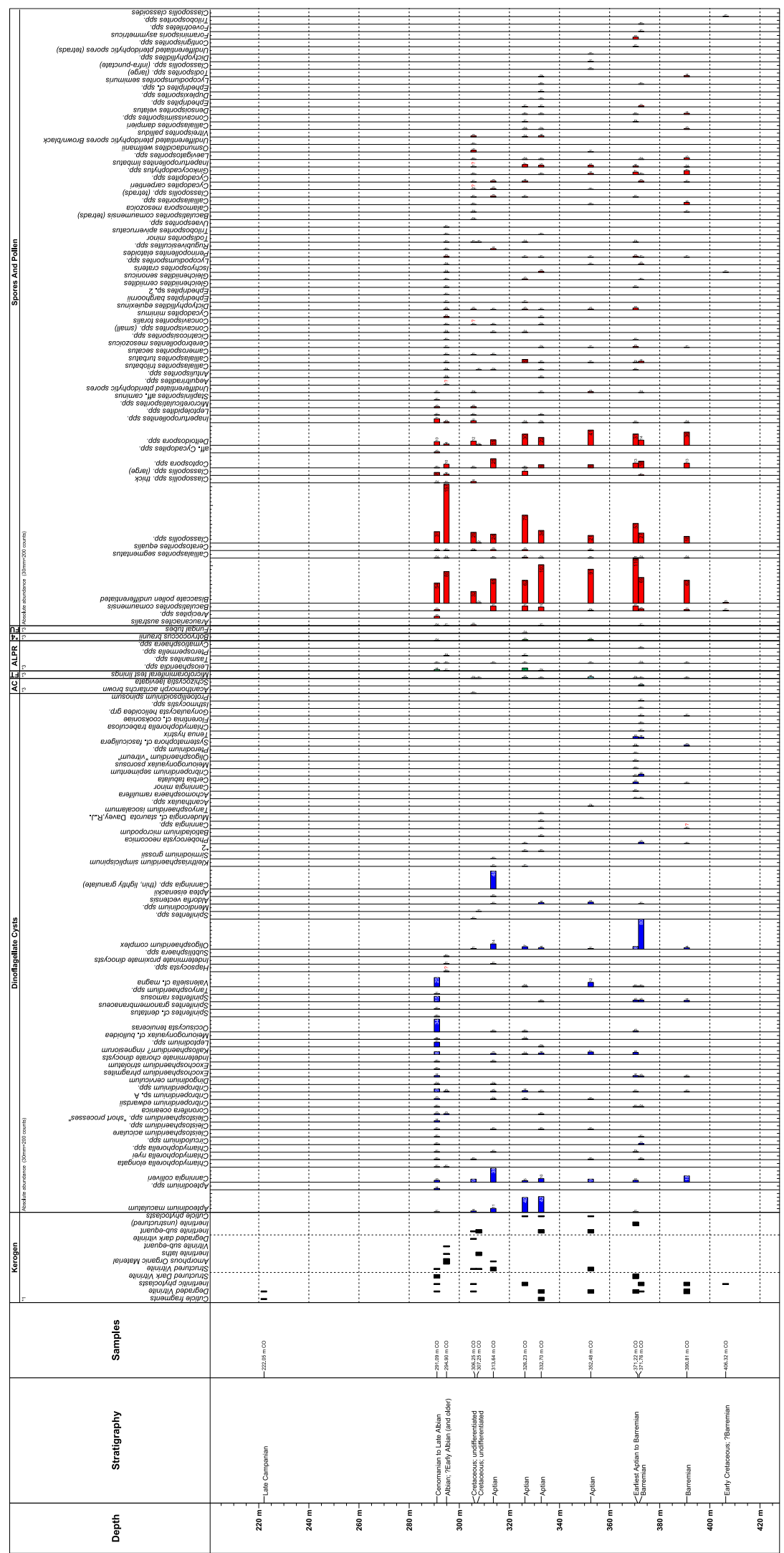

Figure 3. Palynology fossil distribution chart. AC: acritarchs; FT: microforaminiferal tests; ALPR: algae; FU: fungal tubes. 

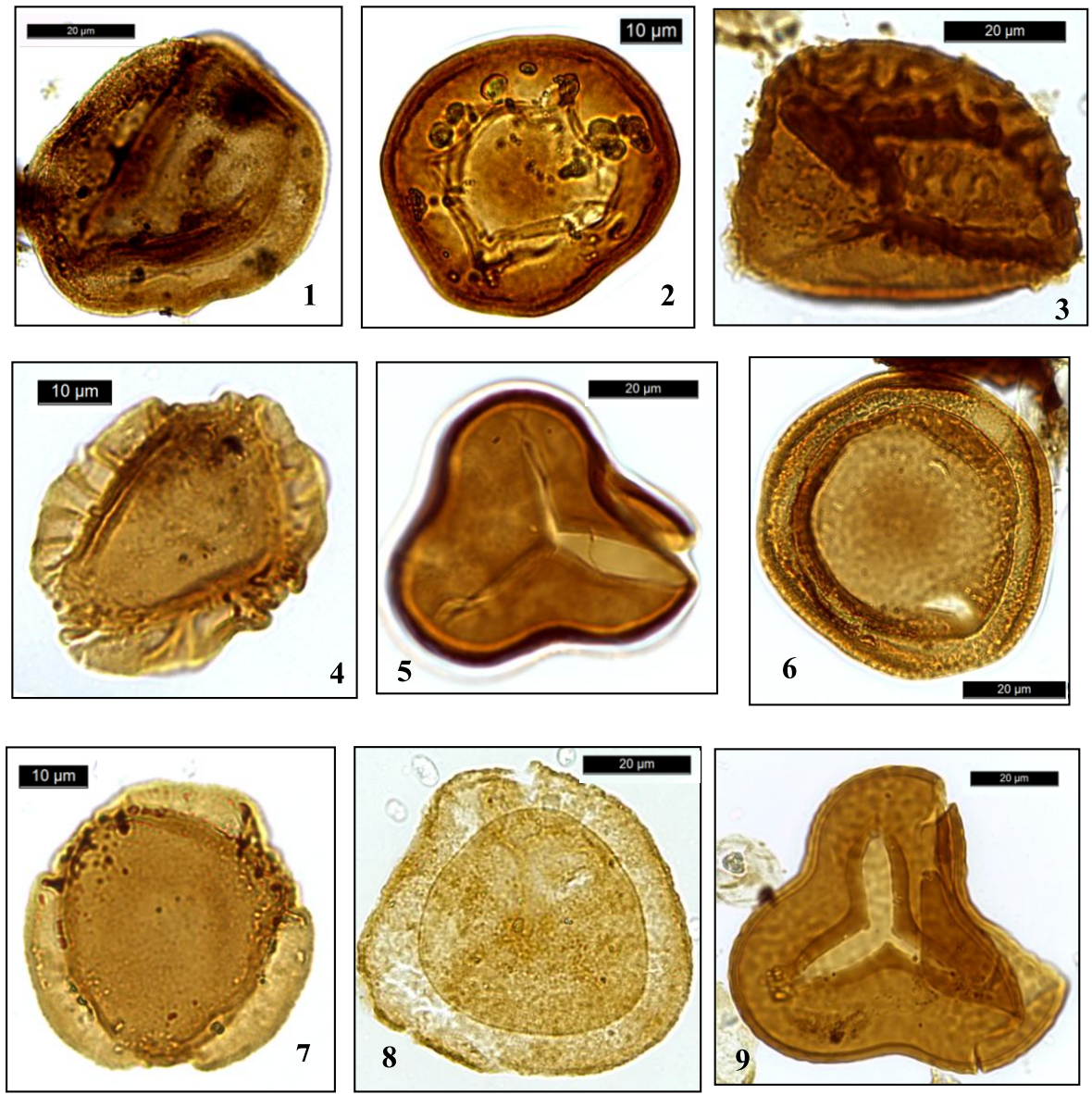

Plate 1. Dinocysts and palynomorphs. (1) Callialasporites spp., DSDP Site, depth $304.2 \mathrm{~m}$; (2) Classopollis spp., DSDP Site 249, depth 371.7 m; (3) ?Foraminisporis spp., DSDP Site 249, depth 332.7 m; (4) Callialasporites dampieri, DSDP Site 249, depth 332.7 m; (5) Cyathidites spp., DSDP Site 249, depth 371.7 m; (6) Callialasporites turbatus, DSDP Site 249, depth 371.7 m; (7) Callialasporites trilobatus, DSDP Site 249, depth 332.7 m; (8) Densosporites spp., DSDP Site 249, depth 332.7 m; (9) Concavissimisporites spp., DSDP Site 249, depth $332.7 \mathrm{~m}$.

water is added to the remaining sediment residue which is decanted into a vial. If the sample is judged to be too thick it is diluted with distilled water and then pipetted on to a glass slide and dried on a hotplate.

The nannofossil logging technique for each sample involved logging three traverses of the suspended/pipette strew slide. The sample is then counted using a cascading counting technique (Styzen, 1997) on 100 fields of view on the suspended/pipette strew slide.

The processing techniques for palynology slide preparation consisted of the following: core samples were scrubbed to remove surface contaminants and crushed. The samples were then immersed in $36 \% \mathrm{HCl}$ to remove carbonates. After termination of any reaction the samples were treated with $48 \% \mathrm{HF}$ for 3-4 days. After termination of reaction the samples were then sieved and $5 \mathrm{~mL}$ of sample was centrifuged in $\mathrm{ZnCl}(2.2 \mathrm{SG})$ to remove mineral matter. These samples were then mounted to produce kerogen slides. The remaining samples were oxidized utilizing $70 \% \mathrm{HNO}_{3}$. The samples were centrifuged and sieved and after checking were mounted on slides.

The logging technique was to count a maximum of 200 specimens per slide and then re-examine the entire slide to log any sparse or single occurrences of other taxa.

\section{Biostratigraphic results}

All quantitative results are presented in Figs. 2 (calcareous nannofossils) and 3 (palynology). Key palynology taxa are illustrated on Plates 1-4 and calcareous nannofossil taxa are illustrated on Plate 5.

Late Campanian. The Chalk samples $222.05 \mathrm{~m}$ (Core 19$3,103-105 \mathrm{~cm}$ ) and $275.72 \mathrm{~m}$ (Core 22-1, 70-72 cm) contain rich calcareous nannofossil assemblages, including Broinsonia parca, Quadrum trifidum, Eiffellithus eximus, and Reinhardtites anthophorus, indicating a late Campanian age.

Plate Cretaceous indeterminate. The sample at $289.6 \mathrm{~m}$ (Core $23-4,108-110 \mathrm{~cm}$ ) contains a sparse and poorly pre- 

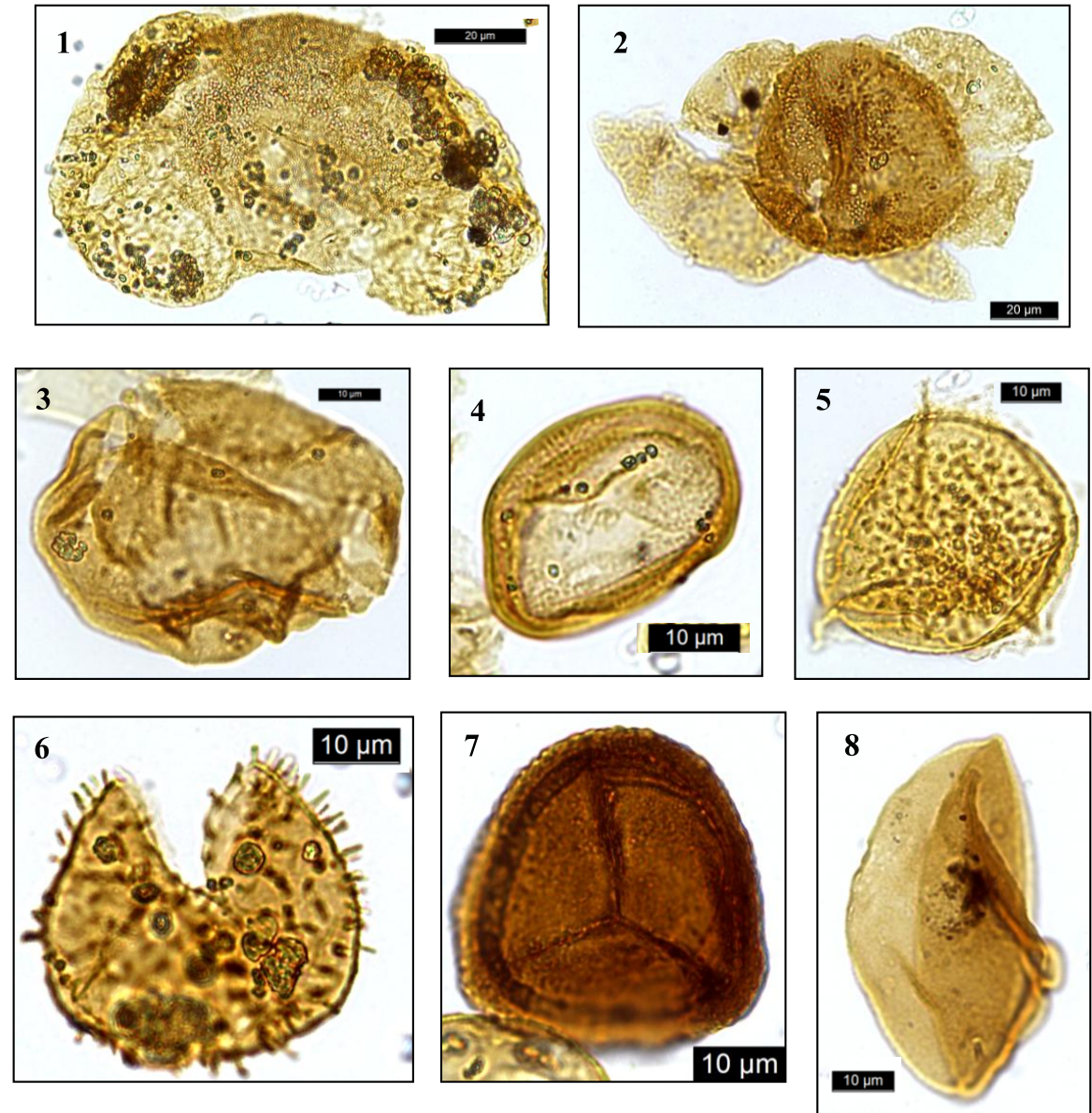

Plate 2. Dinocysts and palynomorphs. (1) Bisaccate pollen undifferentiated, DSDP Site 249, depth $332.7 \mathrm{~m}$; (2) bisaccate pollen undifferentiated, DSDP Site 249, depth 332.7 m; (3) Araucariacites australis, DSDP Site 249, depth 332.7 m; (4) Classopollis spp., DSDP Site 249, depth 332.7 m; (5) aff Aequitriradites spp., DSDP Site 249, depth 294.9 m; (6) Baculatisporites comaumensis, DSDP Site 249, depth 352.4 m; (7) Densoisporites velatus, DSDP Site 249, depth 390.8 m; (8) Cycadopites spp., DSDP Site 249, depth 332.7 m.

served assemblage dominated by Watznaueria barnesiae with Eiffellithus eximus and Arkhangelskiella specillata. These are long-ranging Late Cretaceous taxa.

Cenomanian-late Albian. The claystone at $291.09 \mathrm{~m}$ (Core 23-5, 106.5-108.5 cm) was palynologically analysed. Dinocysts are common, with Occisucysta tenuiceras, Canningia colliveri, Exochosphaeridium striatolatum, Coronifera oceanica, and Cribroperidinium spp. as major constituents. Classopollis torosus is the dominant pollen species and occurs in strata no younger than Cenomanian (Herngreen, 1975; Morgan, 1978). No nannofossil analyses were undertaken on this sample. However, an associated sample at $288.4 \mathrm{~m}$ (Core 23-3, 3-6 cm) contained a planktonic foraminifera assemblage including Ticinella (aff $T$. robertii), Rotalipora appenninica balernaensis and Praeglobotruncana delrioensis (Shipboard Scientific Party, 1974a), suggesting a Cenomanian-late Albian age.

Early Albian to late Aptian (294.9-307.23 m). The age determination is based on sparse palynofloras with increased numbers of Callialasporites at 294.9 (Core 24-1, 88-90 cm) associated with Ephedripites and Classopollis torosus. An increase in pteridophyte spores may argue for an early Aptian or older age (Morgan, 1978), although could be environmentally driven. Dinocysts are very rare at $294.9 \mathrm{~m}$. The other samples in this interval contain dinocysts of early Albianlate Aptian aspect (e.g. Apteodinium maculatum). The interval is barren of calcareous nannofossils.

Early Aptian (313.64-352.48 m). The downhole appearance at $313.64 \mathrm{~m}$ (Core 26-1, 62-64 cm) of the dinocyst species Kleithriasphaeridium simplicispinum indicates an age no younger than Aptian although this species can range into the early Albian mammilatum ammonite zone (Costa and Davey, 1992). Other dinocyst taxa typical of the Aptian, such as Aptea eisenacki (313.64 m), Batioladinium micropodium (326.23 m; Core 27-3, 121-123 cm), and Muderongia cf. staurota $(332.7 \mathrm{~m}$; Core $28-1,21-23 \mathrm{~cm})$, appear in this interval. There is also an increase in Oligosphaeridium spp., Canningia spp., and Apteodinium maculatum. Other 

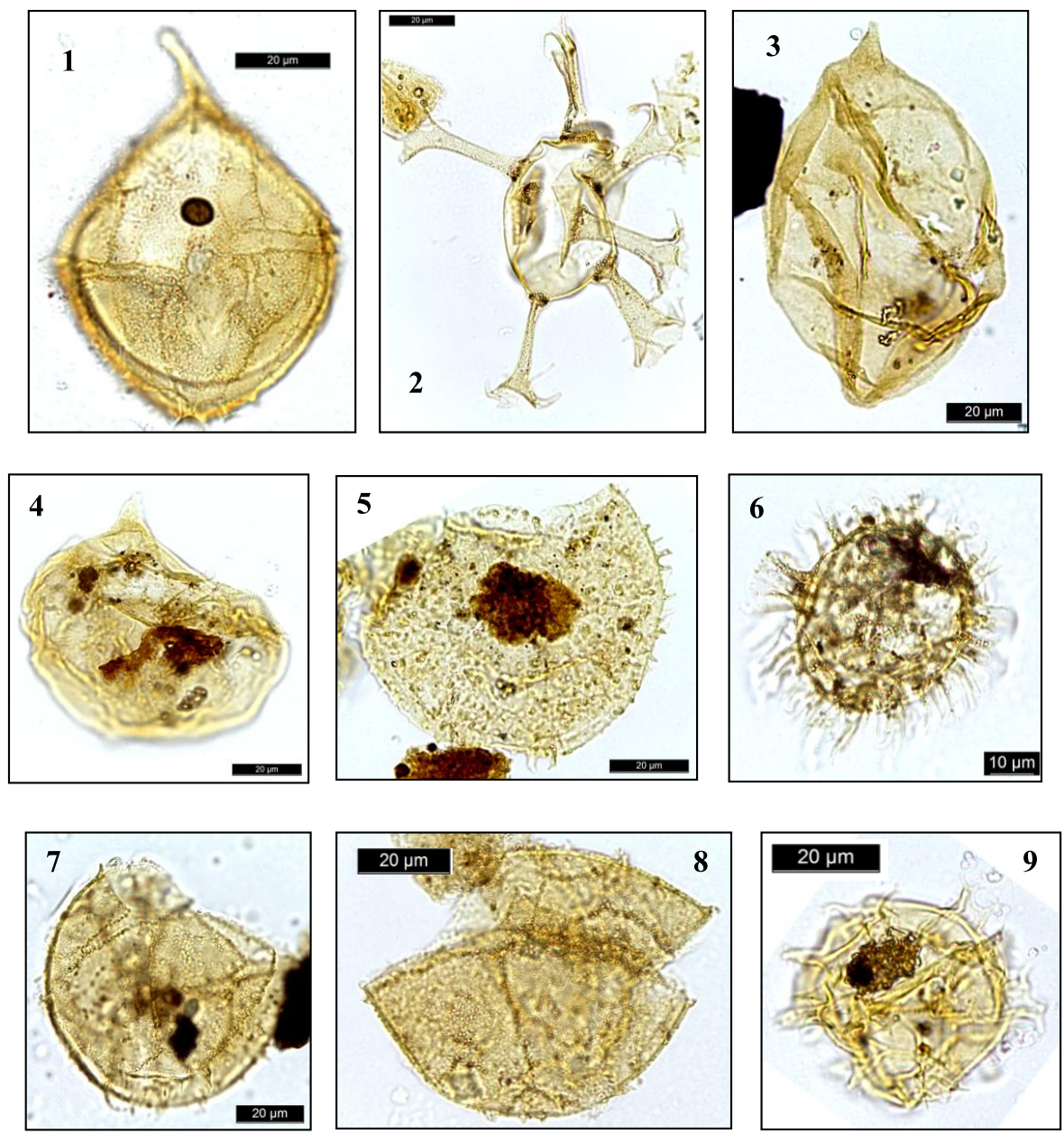

Plate 3. Dinocysts and palynomorphs. (1) Cribroperidinium edwardsii, DSDP Site 249, depth 371.7 m; (2) Oligosphaeridium complex, DSDP Site 249, depth 371.7 m; (3) Apteodinium maculatum, DSDP Site 249, depth 332.7 m; (4) Apteodinium maculatum, DSDP Site 249, depth $332.7 \mathrm{~m}$; (5) Canningia colliveri, DSDP Site 249, depth $332.7 \mathrm{~m}$; (6) Cleistosphaeridium aciculare, DSDP Site 249, depth 291.0 m; (7) Cribroperidinium spp., DSDP Site 249, depth $291.0 \mathrm{~m}$; (8) Occisucysta tenuiceras, DSDP Site 249, depth 291.0 m; (9) Spiniferites ramosus, DSDP Site 249, depth $291.0 \mathrm{~m}$.

dinocysts also appear which do not contradict an early Aptian age, such as Sirmiodinium grossii and Phoberocysta neocomica.

This is supported by the presence of the Turonian-Aptian nannofossil C. achylosus at $332.7 \mathrm{~m}$, which indicates an age no older than Aptian. Furthermore, this species is considered to have its base towards the top of the early Aptian (Erba et al., 1999; Aguado et al., 2014). The absence here of nannofossils with stratigraphic bases in the Albian also supports a pre-Albian age. The assemblages are dominated by the long-ranging species Watznaueria barnesiae.

Earliest Aptian to Barremian $(371.22 \mathrm{~m})$. The last downhole occurrence of the dinocyst Occisucysta tenuiceras and the presence of common Cerbia tabulata at $371.22 \mathrm{~m}$ (Core 30-1, 120-122 cm) indicate earliest Aptian to Barremian. According to Oosting (2004) O. tenuiceras indicates an age no older than earliest Aptian. However, common C. tabulata and
T. hystrix are generally indicative of Barremian assemblages. Only rare, long-ranging calcareous nannofossils (e.g. W. barnesiae) occur in this sample.

Barremian (371.76-393.85 m). The presence of common Phoberocysta neocomica and Cribroperidinium sepimentum suggests a Barremian age as it is associated with the occurrence of Cerbia tabulata. The first occurrence (inception) of C. tabulata occurs at $390.81 \mathrm{~m}$ (Core 31-2, 30-31 cm). The inception point of this species in Europe is considered by Heilmann-Clausen (1987) and others to be no older than early late Barremian (elegans ammonite zone).

The presence of Bownia glabra at $393.8 \mathrm{~m}$, which has its lowest occurrence in the Aptian/late Barremian, supports an age no older than late Barremian at this depth. Although the FO (first occurrence) of B. glabra is considered to be at the Aptian-Barremian boundary, Cooper has found this species in the late Barremian in confidential commercial well sec- 

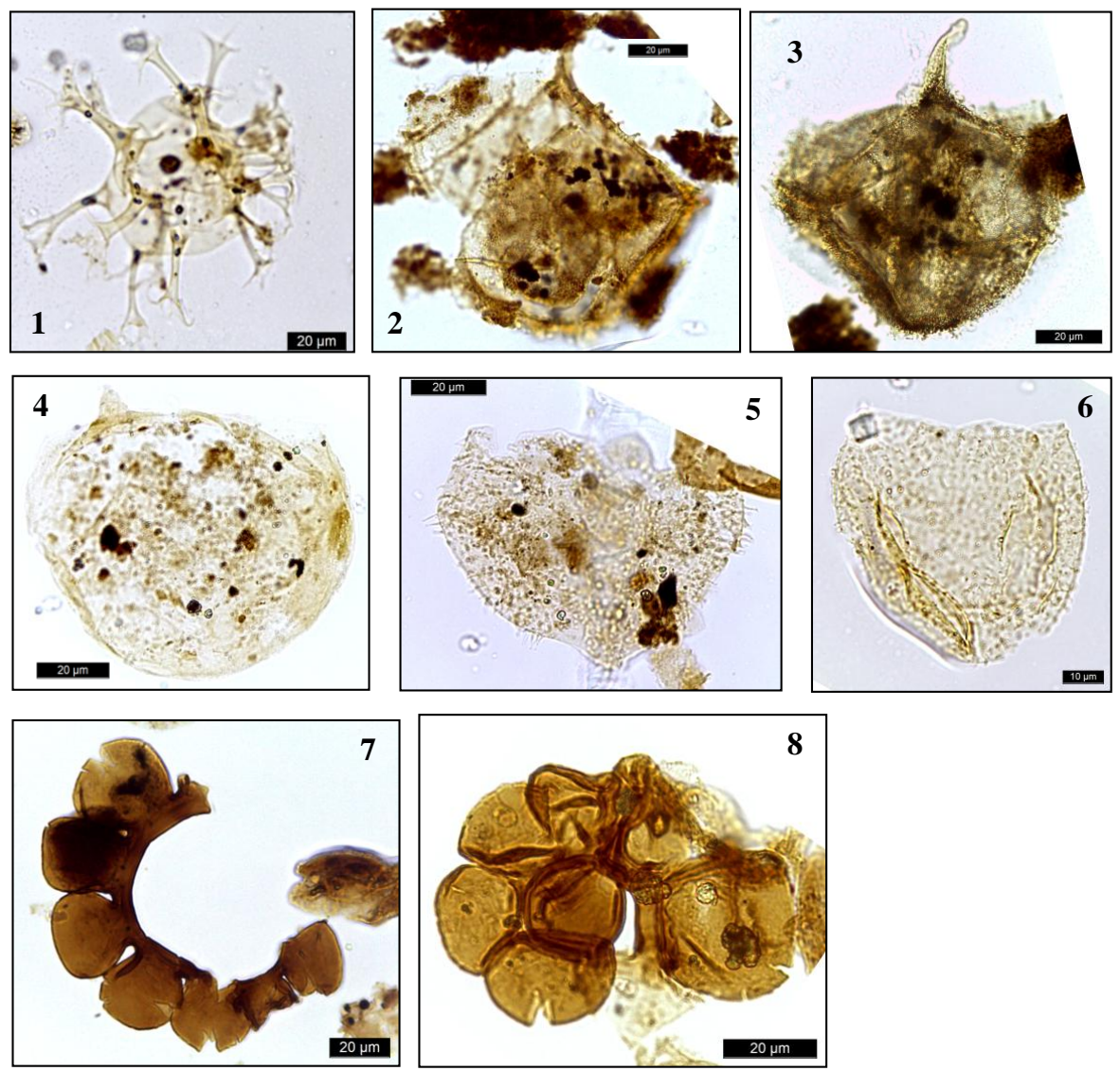

Plate 4. Dinocysts and palynomorphs. (1) Oligosphaeridium complex, DSDP Site 249, depth 326.2 m; (2) Occysucysta tenuiceras, DSDP Site 249, depth $304.2 \mathrm{~m}$; (3) Cribroperidinium edwardsii, DSDP Site 249, depth $326.2 \mathrm{~m}$; (4) Apteodinium spp., DSDP Site 249, depth $326.2 \mathrm{~m}$; (5) Canningia spp., DSDP Site 249, depth $326.2 \mathrm{~m}$; (6) Cerbia tabulata, DSDP Site 249, depth 371.7 m; (7) Microforaminiferal test lining, DSDP Site 249, depth $326.2 \mathrm{~m}$; (8) Microforaminiferal test lining, DSDP Site 249, depth $326.2 \mathrm{~m}$.

tions. Also, an image in Ruckheim et al. (2006) (Fig. 3c) which they recorded in the late Barremian and which was assigned to Broinsonia galloisii is most likely $B$ glabra. W. barnesiae remains a dominant constituent of the assemblage at $393.85 \mathrm{~m}$. Bownia glabra is to be assigned to a new genus which will be formalized by Cooper in 2018 .

Early Cretaceous indeterminate $(406.32 \mathrm{~m})$. A very sparse palynoflora containing exclusively pollen and spores of indeterminate age occurs at this bottommost sample (Core 32$1,130-132 \mathrm{~cm})$. A sparse nannoflora consisting of W. barnesiae and single specimens of Rhagodiscus asper, Cyclagelosphaera margerelli, and Zeugrhabdotus diplogrammus also occur and indicate a general Early Cretaceous age.

\section{Biostratigraphic discussion}

The age assignment of Campanian to 222.05 and $275.72 \mathrm{~m}$ is in agreement with the conclusions of the Shipboard Scientific Party (1974a), as is the late Albian-Cenomanian age assignment at $291.09 \mathrm{~m}$. The early Albian to late Aptian interval
(294.9-307.23 m) is also consistent with the conclusions of the Shipboard Scientific Party (1974a) and later reports.

However the Aptian and Barremian age assignments of the interval below $313 \mathrm{~m}$ (Core 26) in the present analysis differs from the Neocomian age date proposed both in 1974 Shipboard Scientific Party reports and the ValanginianHauterivian age proposed by Riegraf (1989). The concept of the "Neocomian" is indistinct and differs with different authors. The shipboard reports exclude the Barremian stage as does Riegraf. However, Mutterlose (1992) in his nannofossil study of the Lower Cretaceous of ODP Leg 123 (off NW Australia) includes the Barremian in the Neocomian as major floral and faunal changes occur worldwide at the BarremianAptian boundary.

Riegraf (1989) described the foraminifera from 12 radiolarian-rich claystone samples over the depths 315-394 m (Cores 26-31), listing 38 species of calcareous benthic foraminifera dominated by nodosariids and 4 species of agglutinated forams, as well as 13 others in open nomenclature. No planktonic forams were described. The vast majority of the described species are considered endemic or 


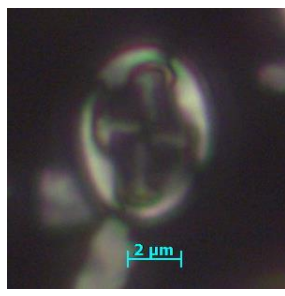

$1 \mathrm{a}$

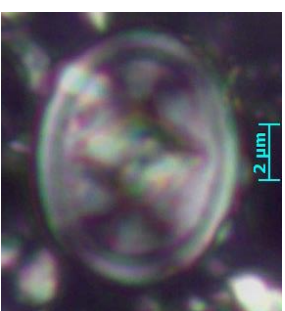

$3 a$

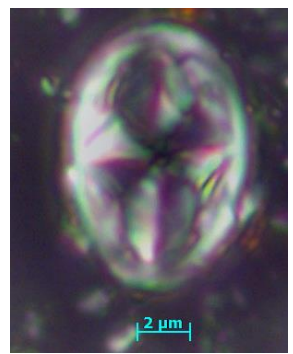

$5 a$

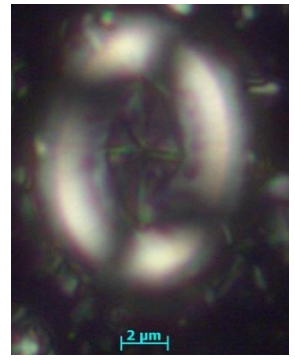

$7 \mathrm{a}$

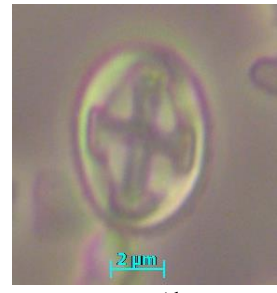

$1 \mathrm{~b}$

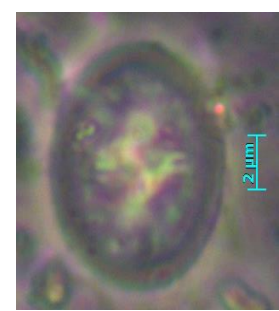

$3 b$

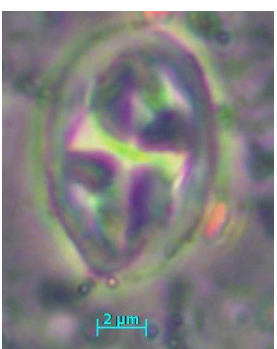

$5 b$

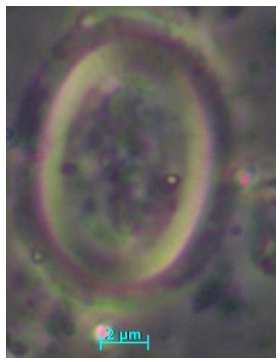

$7 b$

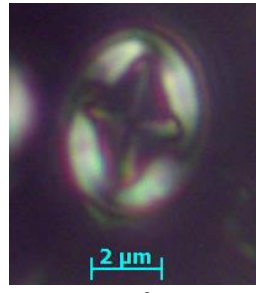

2a

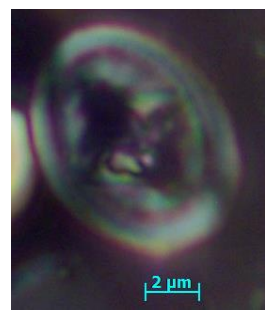

$4 \mathrm{a}$

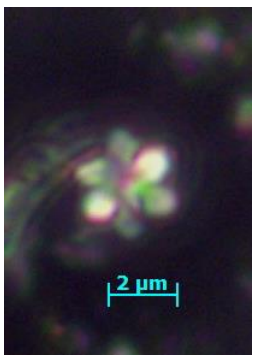

$6 a$

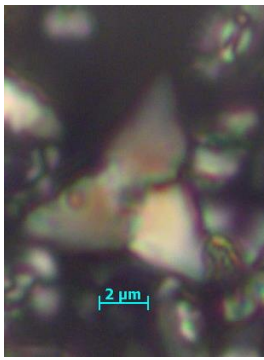

$8 \mathrm{a}$

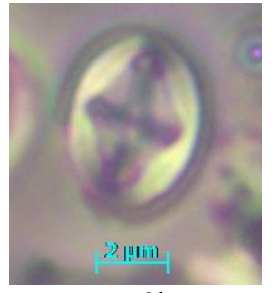

$2 \mathrm{~b}$

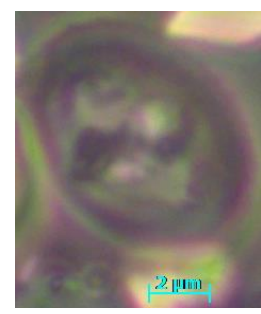

$4 \mathrm{~b}$

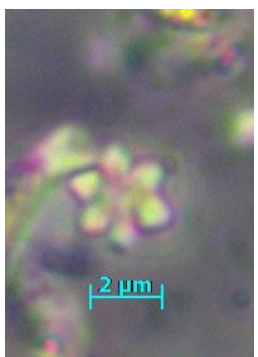

$6 \mathrm{~b}$

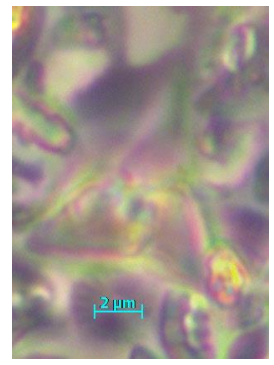

$8 b$

Plate 5. Calcareous Nannoplankton. (1a, b) Salavialea mozambiquensis (gen. et spec. nov., formal designation in press), (1a) crossed nicols, (1b) phase contrast, same specimen, DSDP Site 249, depth $393.8 \mathrm{~m}$; (2a, b) Bownia glabra, (2a) crossed nicols, (2b) phase contrast, same specimen, DSDP Site 249, depth 393.8 m; (3a, b) Reinhardtites levis, (3a) crossed nicols, (3b) phase contrast, same specimen, DSDP Site 249, depth $222.0 \mathrm{~m}$; $(\mathbf{4 a}, \mathbf{b})$ Reinhardtites anthophorus, $\mathbf{( 4 a )}$ crossed nicols, (4b) phase contrast, same specimen, DSDP Site 249, depth 289.6 m; (5a,b) Staurolithites integer, (5a) crossed nicols, (5b) phase contrast, same specimen, DSDP Site 249, depth 222.0 m; (6a, b) Hexalithus gardetae, (6a) crossed nicols, (6b) phase contrast, same specimen, DSDP Site 249, depth $222.0 \mathrm{~m}$; (7a, b) Broinsonia parca, (7a) crossed nicols, (7b) phase contrast, same specimen, DSDP Site 249, depth $222.0 \mathrm{~m}$; (8a, b) Quadrum trifidum, (8a) crossed nicols, (8b) phase contrast, same specimen, DSDP Site 249 , depth $222.0 \mathrm{~m}$.

range throughout the Early Cretaceous with extinction points in Barremian or younger sections. Three of the described species are considered by the author to be restricted to sequences no younger than Hauterivian or Valanginian: Marginulina caelata with rare occurrences (1-5 individuals) at 393, 351, and $315 \mathrm{~m}$; Astacolus microdictyotus with a rare occurrence at $351 \mathrm{~m}$; and Paalzowella feifeli also with a rare occurrence at $315 \mathrm{~m}$.

The actual age range of these benthic forams is uncertain. P. feifeli has been described from the Bathonian to Valanginian at various sites, and Marginulina caelata is a generally Late Jurassic form. Astracolus microdictyotus, 
which is described by Riegraf as having a Late JurassicValanginian range in Madagascar, has been also described from the post-rift Barremian sequence in the neighbouring offshore basins of South Africa (McMillan, 2003). Lenticulina nodosa, another nodosariid encountered by Riegraf in the sample range $315-393 \mathrm{~m}$, is also a common constituent of the early Aptian-Barremian post-rift faunal assemblages of the South African basins as described by McMillan (2003).

The biostratigraphic evidence for younger Early Cretaceous (i.e. Aptian and Barremian) ages for the section below $313 \mathrm{~m}$ is presented in this paper. The presence of the nannofossil species Corollithion achylosus at $332.7 \mathrm{~m}$ indicates an age no older than early Aptian at this level. This occurrence, associated with the absence of typical Albian forms, strongly suggests an Aptian age. Mutterlose (1992) reported first occurrences of C. achylosus in Core 27, ODP Leg 123, Site 766A, of NW Australia, which he dated as early Aptian. The first downhole appearance of the dinocyst Phoberocysta neocomica at $326.23 \mathrm{~m}$, which has an early Aptian extinction level, further suggests an early Aptian age.

The Barremian age assignment for the section below $371.76 \mathrm{~m}$ is based on the occurrences of the dinocyst Cerbia tabulata at $390.81 \mathrm{~m}$ and its common occurrence at $371.76 \mathrm{~m}$. C. tabulata is considered to be no older than late Barremian. The presence of the nannofossil species Bownia glabra at $393.85 \mathrm{~m}$ also indicates an age no older the late Barremian.

\section{Conclusions}

Our biostratigraphic results indicate that the lower sedimentary section of DSDP Site 249 is no older than Barremian. Although $3.1 \mathrm{~m}$ of glassy vesicular basaltic material was recovered from the base of Site 249 (Shipboard Scientific Party, 1974b) no radiometric age dating was performed. $\mathrm{K}-\mathrm{Ar}$ dating on three basalt samples at Site 248 (McKee, 1974) records a Late Cretaceous age of $72.3 \pm 7 \mathrm{Ma}$, with reported late Palaeocene sediments overlying basalt. Although Site 248 is only $143 \mathrm{~km}$ ENE of Site 249 (Fig. 1), it is within the abyssal oceanic plain, rather than on the Mozambique Ridge. A tectonic explanation for the implied difference in the minimum age of the basalts is beyond the scope of this study. Tectonic models proposed by Koenig and Jokat (2006) suggest that the development of a deep water connection on the Mozambique Ridge did not occur until Barremian/Aptian time. The previous biostratigraphic studies, based primarily on benthic foraminifera assemblages, suggested a Hauterivian/Valanginian age for the oldest sediments at DSDP 249 (Shipboard Scientific Party, 1974a; Riegraf, 1989). The results of the current study, indicating a Barremian age for earliest sedimentation over the basement basalt, are consistent with the tectonic model.
Data availability. This micropalaeontological analysis was undertaken as part of a comprehensive geological study of the region which is commercially confidential. All of the raw palaeontological data relevant to this paper are contained in the figures and tables presented in the paper.

Competing interests. The authors declare that they have no conflict of interest.

Acknowledgements. This research used samples provided by the Ocean Drilling Program (ODP). ODP is sponsored by the US National Science Foundation (NSF) and participating countries under management of Joint Oceanographic Institutions (JOI), Inc. Funding for this research was provided by ExxonMobil Exploration Company (EMEC). We also thank Stefania Unida of RPS for the construction of the palynology Plates $1-4$. The authors also thank ExxonMobil Exploration Company (EMEC) for permission to publish this paper.

Edited by: Sev Kender

Reviewed by: two anonymous referees

\section{References}

Aguado, R., de Gea, G. A., and O'Dogherty, L.: Integrated biostratigraphy (calcareous nannofossil, planktonic foraminifera and radiolarians) of an uppermost Barremian-lower Aptian pelagic succession in the Subbetic Basin (southern Spain), Cretaceous Res., 51I, 153-173, 2014.

Bukry, D.: Phytoplankton stratigraphy, offshore East Africa, Deep Sea Drilling Project Leg 25, DSDP Leg 25, Special Studies, in: Deep Sea Drilling Project Reports and Publications, DSDP Volume 25 (publ. 2007), 635-646, https://doi.org/10.2973/dsdp.proc.25.127.1974, 1974.

Cooper, M. K. E.: A new nannofossil genus and new species from the Early Cretaceous and Late Jurassic interval, Journal of Nannoplankton Research, in press, 2018.

Costa, L. and Davey, R. J.: Dinoflagellates of the Cretaceous System, in: Stratigraphic Index of Dinoflagellate Cysts, edited by: Powell, A. J., British Micropalaeontological Society Series, Chapman \& Hall, London, 132-199, 1992.

Erba, E., Channel, J. E. T., Claps, M., Jones, C., Larson, R., Opdyke, B., Premoli Silva, I., Riva, A., Salvini, G., and Torricelli, S.: Integrated stratigraphy of the Cismon Apticore (Southern Alps, Italy): a "Reference Section" for the Barremian-Aptian interval at low latitudes, J. Foramin. Res., 29, 371-391, 1999.

Heilmann-Clausen, C.: Lower Cretaceous dinoflagellate biostratigraphy in the Danish Central Trough, Danmark Geol. Unders, Ser A, 17, 1-89, 1987.

Herngreen, G. F. W.: Palynology of the Middle and Upper Cretaceous strata in Brazil, Med. Rijks. Geol Dienst NS, 26, 39-91, 1975.

Koenig, M. and Jokat, W.: Mesozoic breakup of the Weddell Sea, J. Geophys. Res.-Sol. Ea., 111, B12102, https://doi.org/10.1029/2005JB004035, 2006. 
Koenig, M. and Jokat, W.: Advanced insights into magnetism and volcanism of the Mozambique Ridge and Mozambique Basin in the view of new potential field data, Geophys. J. Int., 180, 158$180,2010$.

Lees, J. A.: Calcareous nannofossil biogeography illustrates palaeoclimate change in the Late Cretaceous Indian Ocean, Cretaceous Res., 23, 537-634, 2002.

Maria, M., Diament, M., and Recqu, M.: Isostatic response of the lithosphere beneath the Mozanbique Ridge (SW Indian Ocean) and geodynamic inplications, Geophys. J. Int., 100, 337-348, 1990.

McKee, E. H.: K-Ar ages of deep sea basalts, Indian ocean, Leg 25, Deep Drilling Projects, DSDP Volume 25, 553-554, https://doi.org/10.2973/dsdp.proc.25.124.1974, 1974.

McMillan, I. K.: Foraminiferally defined biostratigraphic episodes and sedimentation pattern of the Cretaceous Drift succession (Early Barremian to Late Maastrichtian) in seven basins on the South African and southern Namibian continental margin, S. Afr. J. Sci., 99, 537-576, 2003.

Morgan, R.: Albian to Senonian palynology of Site 364, Angola Basin, in: Initial Reports of the Deep Sea Drilling Project, edited by: Bolli, H. and Ryan, W. B. F., 40, 915-951, https://doi.org/10.2973/dsdp.proc.40.125.1978, 1978.

Mutterlose, J.: Lower Cretaceous nannofossil biostratigraphy off northwestern Australia (Leg 123), Proceedings of the Ocean Drilling Program, Scientific Results, 123, 343-362, 1992.

Oosting, A. M.: Palaeoenvironmental and Climatic Changes in Australia during the Early Cretaceous, PhD thesis, James Cook University, LPP Publication Series no. 17, Queensland, Australia, 2004.
Riegraf, W.: Benthonische Schelf-Foraminiferen aus dem Valanginium-Hauterivium (Unterkreide) des Indischen Ozeans suedwestlich Madagaskar (Deep Sea Drilling Project Leg 25, Site 249), Geol. Rundsch., 78/3, 1047-1061, 1989.

Roth, P. H. and Thierstein, H.: Calcareous nannoplankton of Leg 14 of the Deep Sea Drilling Project, Deep Sea Drilling Project Reports and Publications, DSDP Vol 14 (publ. 2007), 421-485, https://doi.org/10.2973/dsdp.proc.14.116.1972, 1972.

Rueckheim, S. Bornemann, J., and Mutterlose, J.: Integrated stratigraphy of an Early Cretaceous (Barremian-Early Albian) North Sea borehole (BGS 81/40), Cretaceous Res., 27, 447-463, 2006.

Sanfilippo, A. and Riedel, W. R.: Some radiolarian samples from the western Indian Ocean, DSDP Leg 25, DSDP Leg 25, Special Studies, in: Deep Sea Drilling Project Reports and Publications, DSDP Vol 25 (publ. 2007), 657-661, https://doi.org/10.2973/dsdp.proc.25.129.1974, 1974.

Shipboard Scientific Party: Site 249, Part 1, Site Reports, Biostratigraphy, in: Deep Sea Drilling Project Reports and Publications, DSDP Vol 25 (publ. 2007), 296-300, https://doi.org/10.2973/dsdp.proc.25.110.1974, 1974a.

Shipboard Scientific Party: Site 249, Part 1, Site Reports, Lithology, in: Deep Sea Drilling Project Reports and Publications, DSDP Vol 25 (publ. 2007), 292-295, https://doi.org/10.2973/dsdp.proc.25.110.1974, 1974b.

Styzen, M. J.: Cascading counts of nannofossil abundance, Journal of Nannoplankton Research, 19, p. 49, 1997.

Tucholke, B. E., Houtez, R. E., and Barrett, D. M.: Continental crust below the Agulhas Plateau, southwest Indian Ocean, J. Geophys. Res., 86, 3791-3806, 1981. 